\title{
Retrospective Evaluation of Neonatal Morbidities of Full-term and Early Term Newborns
}

\section{Erken Term ve Tam Zamanlı Term Yenidoğanların Morbiditelerinin Retrospektif Olarak Karşılaştırılması}

Erbu Yarcı (0000-0003-4434-0958), Nurdan Uraş (0000-0003-3382-7226)

University of Health Sicences Turkey, Zekai Tahir Burak Womens' Health Training and Research Hospital, Clinic of Neonatology, Ankara, Turkey

\section{Keywords}

Early term, neonatal outcome, morbidity, neonatal intensive care unit

\section{Anahtar kelimeler \\ Erken term, neonatal sonuç, morbidite, yenidoğan yoğun bakım servisi}

Received/Geliş Tarihi : 28.04.2021

Accepted/Kabul Tarihi : 13.05.2021

DOI:10.4274/jcp.2021.0022

Address for Correspondence/Yazışma Adresi: Erbu Yarc1 MD, University of Health Sicences Turkey, Zekai Tahir Burak Womens' Health Training and Research Hospital, Clinic of Neonatology, Ankara, Turkey

E-mail: erbuyarci@yahoo.com

\begin{abstract}
Introduction: Newborns having a gestational age between 37 to $416 / 7$ weeks are defined as term newborn. The aim of the study was to investigate the rates and causes of hospitalization, and the differences in neonatal morbidities between early-term and full-term infants as a single-center experience in our hospital.

Materials and Methods: This retrospective study was carried out in a tertiary neonatal intensive care unit between January 2013 and December 2014. Maternal characteristics and comorbidities; neonatal characteristics, length of hospital stay, and neonatal morbidities were recorded. Primary outcome measure was need for neonatal intensive care unit (NICU) admission.

Results: Maternal comorbidities, ceserean delivery, low birth weight, SGA and multiple gestations were found to be higher in early-term infants and earlyterm infants were at higher risk for respiratory morbidities, respiratory support requirement, hypoglycemia and intravenous antibiotic therapy. After multivariate logistic regression analyses, only higher risk for respiratory morbidity persisted (OR:1.28 [1.02-1.59]; $\mathrm{p}=0.02$ ). In contrast to that, full-term infants was found to be at higher risk for hypernatremia compared to early-term infants.

Conclusions: Early term birth is associated with a higher neonatal morbidity and NICU admissions, and gestational age is known to be the most important determinant of this situation. With advanced maternal care and better understanding of the factors causing early term birth will lead to prevention and successfull management of this risk group.
\end{abstract}

$\ddot{\mathbf{O} z}$

Giriş: Gestasyonel yaşı 37 ile 416/7 hafta arasında olan bebekler term yenidoğan olarak tanımlanır. Bu çalışmada, hastanemizde doğan ve izlenen erken term ve tam zamanlı term yenidoğanların neonatal morbiditeler, hastaneye yatış oranları ve nedenleri açısından karşılaştırılması amaçlanmıştır.

Gereç ve Yöntem: Retrospektif olarak yürütülen bu çalışmada Ocak 2013 ile Aralık 2014 tarihleri arasında 3. basamak yenidoğan yoğun bakım (YDYB) servisinde yatırılarak izlenen term yenidoğanlar değerlendirilmiştir. Anneye ait özellikler, eşlik eden hastalıklar, yenidoğanların demografik özellikleri, hastane yatış süresi ve neonatal morbiditeler kayıt altına alınmış olup, çalışmanın birincil sonucu yenidoğan yoğun bakım ünitesine yatış gereksinimidir.

Bulgular: Maternal eşlik eden hastalıklar, sezaryen doğum, düşük doğum ağırlığı, gestasyon yaşına göre küçük yenidoğanlar ve çoğul gebelikler erken term grubunda daha yüksek saptanmış olup, solunumsal morbiditeler, solunum desteği gereksinimi, hipoglisemi ve intravenöz antibiyotik gereksinimi açısından erken term grubunda daha yüksek saptanmıştır. Çoklu regresyon analizi sonrası sadece solunumsal morbiditeler açısından yüksek riskin devam ettiği görüldü 
(RR:1.28 [1.02-1.59]; $\mathrm{p}=0.02$ ). Buna karşın, hipernatremi tam zamanlı term grubunda erken term grubuna göre daha yüksek saptandi.

Sonuç: Erken termde doğum daha yüksek oranda neonatal morbidite ve YDYB yatışı ile ilişkili olup gestasyonel yaş bu durumu belirleyen en önemli faktördür. Daha iyi maternal bakım ve erken doğuma yol açabilecek faktörlerin belirlenmesi bu riskli grupta olası sorunların önlenmesini ve başarılı şekilde yönetilmesini sağlayacaktır.

\section{Introduction}

Infants born 37 weeks and 41 weeks 6 days from the last menstrual period are defined as term newborns (1). Babies born within this five-week period were generally considered as a homogeneous group (2). Morbidities caused by physiological immaturity in the neonatal period has been frequently examined in premature infants $(3,4)$. The results of current studies showed that neonatal morbidities decrease in later gestational weeks and babies born at gestational age of 37 and 38 weeks have higher morbidity compared to babies born at 39 weeks (5).

Transient tachypnea of the newborn (TTN), pneumonia, respiratory distress syndrome (RDS), feeding difficulties and hypothermia are more common in infants born at 37 and 38 weeks of gestation than infants born after 38 weeks of gestational age $(6,7)$.

Babies having a gestational age between 37 and 38 weeks also have a higher risk for neurodevelopmental and behavioral problems, asthma / wheezing, and hospital admissions within the first five years of life than those born after 38 weeks of gestational age (8).

As a result of these data, the American College of Obstetrics and Gynecology (ACOG) proposed "early term" for 37 and 38 weeks of gestational age, and "fullterm" for 39 and 40 weeks of gestational ages (9).

The aim of our study was to investigate the rates and causes of hospitalization, and the differences in neonatal morbidities between early-term and full-term infants as a single-center experience in our hospital.

\section{Materials and Methods}

This retrospective study was carried out between January 2013 and December 2014 in the Neonatal Intensive Care Unit (NICU) of Zekai Tahir Burak Womens' Health Training and Research Hospital.

The terminology used for evaluation was, term newborn (37 weeks - 41 weeks 6 days post menstrual age; PMA), early term (37 weeks - 38 weeks 6 days PMA), full-term (39 weeks - 41 weeks 6 days PMA).
Gestational age was determined primarily by ultrasonographic evaluation performed in the first trimester and by calculation based on the last menstrual period in follow-up or by clinical evaluation after delivery.

Maternal demographic data were obtained from electronic system records. The maternal age at the time of delivery, presence of multiple pregnancies and concomitant maternal diseases were recorded. Newborns' characteristics were obtained from medical records. The primary outcome of the study was hospitalization in the NICU. Respiratory disorders, need for respiratory support, duration of hospitalization, need for intravenous (iv) fluid therapy and iv antibiotic (AB) therapy, concomitant metabolic disorders, and indirect hyperbilirubinemia requiring treatment of the hospitalized newborns were evaluated as secondary outcomes.

Causes of respiratory distress were recorded as TTN, congenital pneumonia, meconium aspiration, and other causes of respiratory distress (such as sepsis) and hospitalization in the intensive care unit without any diagnostic test or intervention. The need for respiratory support was grouped as oxygen therapy with nasal cannula, oxygen therapy with hood, mechanical ventilation, and surfactant administration.

Primary gastrointestinal pathology or conditions that cause feeding intolerance or hypoglycemia were indications for intravenous fluid therapy. Hypoglycemia, hypernatremia, hyponatremia, hypocalcemia, hypomagnesemia were recorded as metabolic disorders.

Indications for intravenous antibiotic therapy were suspected sepsis, early onset neonatal sepsis, late onset neonatal sepsis, omphalitis, infection and other causes of antibiotic use.

Treatment for indirect hyperbilirubinemia with phototherapy was evaluated according to AAP nomograms according to gestational age and concomitant risk factors.

Patients with congenital anomalies or malformations (such as gastroschisis, congenital 
diaphragmatic hernia, chromosomal anomaly, complex congenital heart disease) and without family consent were excluded from the study.

Informed consent was obtained from the parents of all newborns participating in the study. Zekai Tahir Burak Womens' Health Training and Research Hospital Planning Board approved the study. The Ethics committee certificate date and no was 02.06.2014-0020.

\section{Statistical analysis}

Statistical analysis were performed with SPSS 20.0 for windows. Qualitative variables were expressed as percentages. Bivariate analysis was performed using chi-square test and Fischer-exact test. Continuous variables with normal distribution were expressed as mean (SD) and compared using t-test.

As the primary and secondary results were twocomponent, the relative risk (OR) was calculated by logistic regression analysis. Final results were reported as a relative risk (CI 95\%) after correction for sex, gestational age, mode of delivery and maternal age.

\section{Results}

Between 1 January 2013 and 31 December 2014, 37087 live births were recorded in Zekai Tahir Burak Womens' Health Training and Research Hospital. The gestational age of $30137(81,2 \%)$ of these live births was between 37 weeks and 41 weeks and 6 days.

29941 infants were evaluated as study population. While $11446(30,8 \%)$ of 37087 live births were early term and $18495(49,8 \%)$ were full-term.

A total of 5238 newborns were admitted to NICU between 2013 and 2014, and 1514 of these newborns met the study criteria (29\%). While 814 $(53,8 \%)$ of the 1514 term newborns admitted to NICU were early term, $700(46,2 \%)$ were full-term newborns(Figure 1).

Concomitant maternal diseases were detected in $130(15 \%)$ mothers in the in the early term group, while $56(8 \%)$ mothers in the full-term term group had concomittant diseases. Statistically significant higher maternal disease was detected in the early term group $(\mathrm{p}=0.011)$.

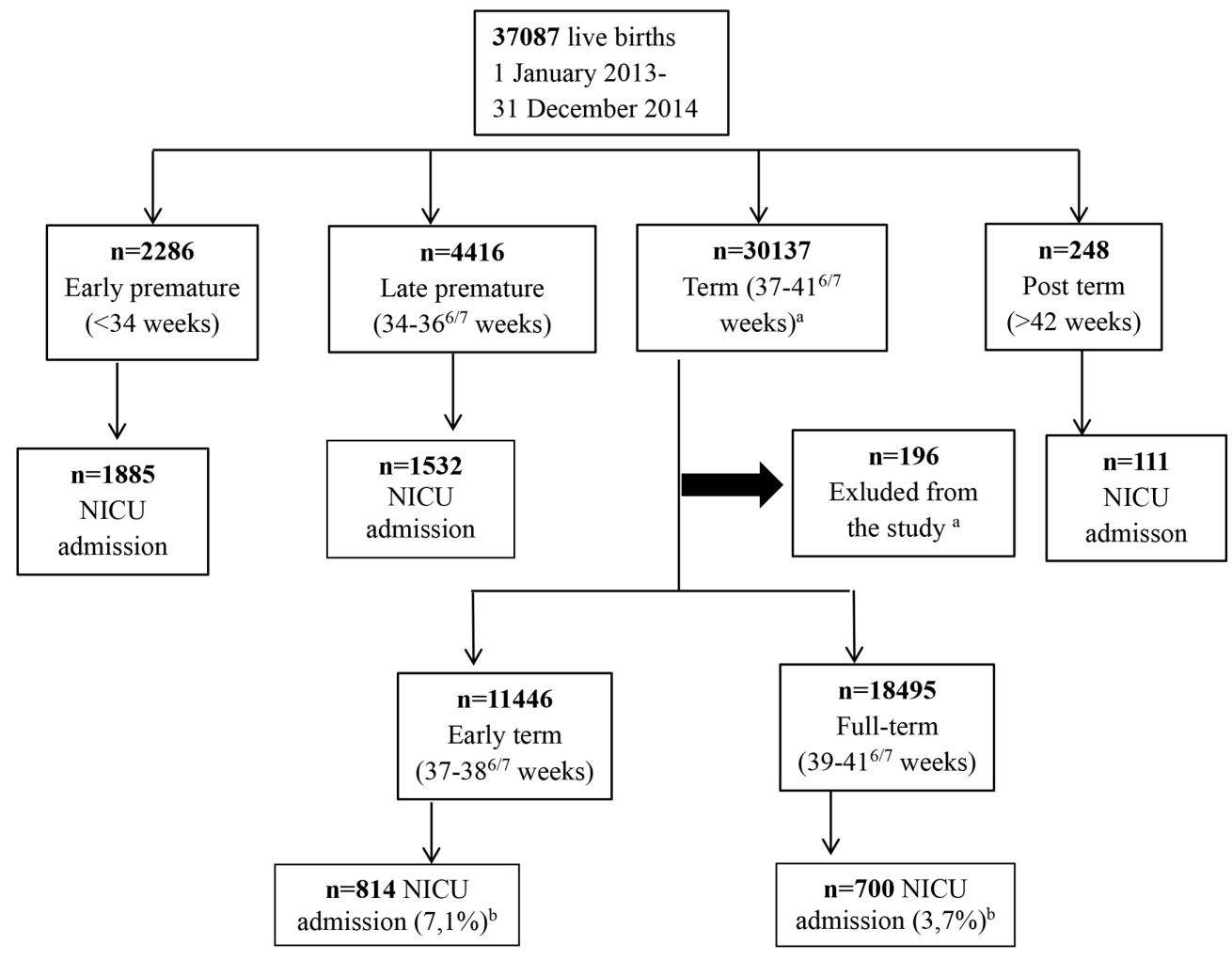

Figure 1. Flow chart of study cohort

NICU: Neonatal intensive care unit, ${ }^{a}$ Includes all congenital malformations and chromosomal abnormalities requiring hospitalization in the NICU, ${ }^{b}$ Indicates the percentage of hospitalization in the NICU at the indicated gestational age 
The most common maternal disease was diabetes in both groups. Maternal characteristics are presented in Table 1.

The groups did not differ for birth weight $(\mathrm{p}=0.52)$. In contrast, low birth weight (LBW) was detected in $157(19,3 \%)$ patients in the early term group and 43 $(6,1 \%)$ patients in the full-term group. A significantly

Table 1. Demographic characteristics of mothers included in the study

\begin{tabular}{|c|c|c|c|}
\hline Characteristics & $\begin{array}{l}\text { Early Term } \\
\text { Group }^{\mathrm{a}} \\
(\mathrm{n}=814)\end{array}$ & $\begin{array}{l}\text { Full-term } \\
\text { Group }^{\mathrm{b}} \\
(\mathrm{n}=700)\end{array}$ & $\begin{array}{l}\mathrm{p} \\
\text { value }\end{array}$ \\
\hline \multicolumn{4}{|l|}{ Maternal age (years) } \\
\hline Mean \pm SD & $28,2 \pm 5,9$ & $28,1 \pm 5,9$ & $>0.05$ \\
\hline$\leq 18$ years, $\mathrm{n}(\%)$ & $23(2,8)$ & $16(2,3)$ & $>0.05$ \\
\hline Maternal diseases, $\mathbf{n}(\%)$ & $130(16)$ & $56(8)$ & \\
\hline Diabetes & 74 & 36 & \\
\hline Hypotyroidism & 21 & 9 & \\
\hline Preeclampsia & 19 & 9 & 0.011 \\
\hline Eclampsia & 5 & 1 & \\
\hline Epilepsy & 4 & 1 & \\
\hline Cholestasis & 2 & - & \\
\hline Delivery with $\mathrm{C} / \mathrm{S}$ & $505(62 \%)$ & $350(50 \%)$ & 0.0001 \\
\hline \multicolumn{4}{|c|}{ aPostmenstrual age to 37 - to $386 / 7$ weeks, ${ }^{\text {b}}$ Postmenstrual age to 39 to $416 / 7$ weeks } \\
\hline \multicolumn{4}{|c|}{ Table 2. Demographical characteristics of study population } \\
\hline Characteristics & $\begin{array}{l}\text { Early Term }{ }^{a} \\
(n=814)\end{array}$ & $\begin{array}{l}\text { Full-Term }{ }^{\mathrm{b}} \\
(\mathrm{n}=700)\end{array}$ & $\mathrm{p}$ value \\
\hline Male, $\%$ & 58,7 & 57,1 & 0.56 \\
\hline \multicolumn{4}{|l|}{ Birth weight, $\mathrm{g}$} \\
\hline Mean and SD & $2999 \pm 574$ & $3361 \pm 559$ & $>0.05$ \\
\hline$\geq 2500 \mathrm{~g}, \%$ & 80,7 & 93,9 & 0.001 \\
\hline$<2500 \mathrm{~g}, \%$ & 19,3 & 6,1 & 0.001 \\
\hline $\mathrm{SGA}^{\mathrm{c}}, \%$ & 14,6 & 5,2 & 0.0001 \\
\hline $\mathrm{LGA}^{\mathrm{d}}, \%$ & 5 & 13,2 & 0.0001 \\
\hline Multiple pregnancies, $\%$ & 3,8 & 1 & 0.0001 \\
\hline \multicolumn{4}{|l|}{ APGAR score $\leq 5, \%$} \\
\hline 1. minute & 4,7 & 8,2 & 0,006 \\
\hline 5. minute & 0,7 & 1,7 & 0.09 \\
\hline Cord blood pH & $\begin{array}{l}7,28 \\
(7,10-7,34) \\
\end{array}$ & $\begin{array}{l}7,27 \\
(7,01-7,34) \\
\end{array}$ & $0.029^{\mathrm{e}}$ \\
\hline \multicolumn{4}{|c|}{$\begin{array}{l}\text { SGA: Small for gestational age, LGA: Large for gestational age, }{ }^{\text {a }} \text { Postmenstrual } \\
\text { age of } 37 \text { to } 386 / 7 \text { weeks, }{ }^{b} \text { Postmenstrual age of } 39 \text { - to } 416 / 7 \text { weeks, }{ }^{\circ} \text { Birth weight } \\
\leq 10 \text { th percentile according to growth curves by Fenton ( } 24) \text {, }{ }^{\mathrm{d} B i r t h} \text { weight } \geq 90 \text { th } \\
\text { percentile according to growth curves by Fenton }(24) \text {, }{ }^{\circ} \text { Mann-Whitney U test was } \\
\text { used for comparison. }\end{array}$} \\
\hline
\end{tabular}

higher LBW newborns was detected in the early term group $(\mathrm{p}=0.0001)$.

SGA infant rate was $14,6 \%(119 / 814)$ in the early term group and $5,2 \%(36 / 700)$ in the full-term term group, with a statistically significant difference $(\mathrm{p}=$ $0.0001)$. In contrast, the LGA infant rate was $13,2 \%$ $(92 / 700)$ in the full-term group and 5\% (41/814) in the early term group. The LGA ratio was significantly higher in the full-time term group $(\mathrm{p}=0.031)$.

Multiple pregnancies were found to be significantly higher in early term group compared to full term group $(3,8 \%$ and $1 \% ; \mathrm{p}=0.0001)$.

814 early term newborns were hospitalized in the NICU, accounted for $7,1 \%$ of all early term neonates,

Table 3. Comparison of Morbidities of Early Term and Full Term Newborns

\begin{tabular}{|c|c|c|c|}
\hline Variables & $\begin{array}{l}\text { Early Term }^{a} \\
(\mathrm{n}=814)\end{array}$ & $\begin{array}{l}\text { Full Term } \\
(\mathrm{n}=700)\end{array}$ & $\mathrm{p}$ value \\
\hline $\begin{array}{l}\text { NICU admission (live } \\
\text { births at this gestational } \\
\text { age) }\end{array}$ & $\begin{array}{l}7,1 \% \\
(11446)\end{array}$ & $\begin{array}{l}3,7 \% \\
(18495)\end{array}$ & $<0.05^{\mathrm{c}}$ \\
\hline $\begin{array}{l}\text { Duration of hospital } \\
\text { stay, day, mean } \pm \text { SD }\end{array}$ & $5,9 \pm 4,3$ & $5,7 \pm 4,1$ & 0.24 \\
\hline $\begin{array}{l}\geq 5 \text { days of hospital stay } \\
(\%)\end{array}$ & $455(55,8)$ & $378(54)$ & 0.46 \\
\hline \multicolumn{4}{|l|}{ Respiratory distress } \\
\hline Morbidity $^{\mathrm{d}}, \mathrm{n}(\%)$ & $425(52,2)$ & $321(45,8)$ & 0.01 \\
\hline $\begin{array}{l}\text { Respiratory support }{ }^{\mathrm{e}} \text {, } \\
\mathrm{n}(\%)\end{array}$ & $423(51,9)$ & $319(45,5)$ & 0.03 \\
\hline $\begin{array}{l}\text { MV* or entubation, } \mathrm{n} \\
(\%)\end{array}$ & $72(8,8)$ & $44(6,2)$ & 0.06 \\
\hline Surfactant use, n (\%) & $29(3,5)$ & $15(2,1)$ & 0.09 \\
\hline $\begin{array}{l}\text { Metabolic disorders, } \\
\mathrm{n}(\%)\end{array}$ & $181(22,3)$ & $137(19,5)$ & 0.01 \\
\hline $\begin{array}{l}\text { Hypoglycemia, } \\
\mathrm{n}(\%)\end{array}$ & $142(17,5)$ & $95(13,5)$ & 0.03 \\
\hline $\begin{array}{l}\text { Hypernatremia, } \\
\mathrm{n}(\%)\end{array}$ & $20(2,5)$ & $39(5,5)$ & 0.02 \\
\hline $\begin{array}{l}\text { iv fluid therapy, } \\
\mathrm{n}(\%)\end{array}$ & $525(35,5)$ & $224(32)$ & 0.15 \\
\hline $\begin{array}{l}\text { iv antibiotic treatment, } \\
\mathrm{n}(\%)\end{array}$ & $325(40)$ & $226(32,4)$ & 0.002 \\
\hline $\begin{array}{l}\text { İndirect } \\
\text { hyperbilirubinemia }{ }^{\mathrm{f}}, \\
\mathrm{n}(\%)\end{array}$ & $335(41,2)$ & $277(39,6)$ & 0.56 \\
\hline
\end{tabular}

NICU: Neonatal intensive care unit, MV: Mechanical ventilation, ${ }^{\text {aPostmenstrual }}$

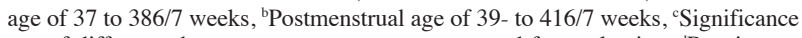
test of difference between two percentages was used for evaluation, ${ }^{\mathrm{d}}$ Respiratory distress requiring NICU admission, ${ }^{e} \mathrm{Need}$ for respiratory support including oxygen therapy with hood, nCPAP or mechanical ventilation, ${ }^{\mathrm{f}} \mathrm{Need}$ for treatment of indirect hyperbilirubinemia with phototherapy, IVIG or exchange transfusion 
whereas 700 full-term newborns were admitted to the NICU and accounted for 3,7\% of full-term neonates. A higher hospitalization in the NICU was found in the early term group $(\mathrm{p}<0.05)$.

The groups did not differ in terms of duration of hospitalization $(\mathrm{p}=0.24)$ and hospital stay longer than 5 days $(\mathrm{p}=0.46)$

Respiratory morbidities were found to be significantly higher in early term group compared to full-term group ( $p=0.014)$. The most common cause of respiratory distress in both groups was TTN $(n=611)$, congenital pneumonia $(n=68)$ and meconium aspiration $(n=40)$, respectively. The cause of respiratory distress in $27(1,8 \%)$ patients was not primary respiratory system diseases, but it was noted as a secondary finding of metabolic disorders such as sepsis, hypoglycemia and other morbidities.

The early term group had higher need for respiratory support compared to full term group (423/814, 319/700; $\mathrm{p}=0.013$ ).

In terms of surfactant treatment, $29(3,5 \%)$ patients were administered surfactant in the early term group, while $15(2,1 \%)$ patients needed surfactant in the fullterm term group.

When the groups were compared for iv fluid treatment due to hypoglycemia or feeding difficulty; the groups did not differ significantly $(p>0.05)$

The most common metabolic disorder in the study population was hypoglycemia $(n=237)$. When compared for metabolic disorders, metabolic disorders were detected in $181(22,3 \%)$ patients in the early term group, and in $137(19,5 \%)$ newborns in the full-term group ( $\mathrm{p}=0.013)$. Hypoglycemia was significantly higher in the early term group $(n=142 ; 17,5 \%)$ compared to full-term group $(\mathrm{n}=95 ; 13,5 \%),(\mathrm{p}=0.03)$. Hypernatremia was found in $20(2,5 \%)$ newborns in the early term group and $39(5,5 \%)$ newborns in the full-term group. The full-term group had significantly higher hypernatremia compared to early term group $(\mathrm{p}=0.002)$.

Intravenous antibiotic therapy was applied for the following reasons: infection, early-onset sepsis, late-onset sepsis, and infections without a focus with accompanying maternal risk factors (early membrane rupture, chorioamnionitis, urinary tract infection, positive cervical culture).

In the early term group, 325 (40\%) newborns received iv antibiotic treatment, while in the full-term group the number of newborns receiving iv antibiotic treatment was $226(32,4 \%)$, and the early term group had statistically significant higher antibiotic requirement $(\mathrm{p}=0002)$.

Indirect hyperbilirubinemia (IHB) needing phototherapy according to gestational age and risk factors was evaluated in the study population. The groups did not differ in terms of IHB needing phototherapy ( $\mathrm{p}>0.05)$.

In our study, early term newborns was found to be at higher risk for respiratory morbidity, need for respiratory support, hypoglycemia, and antibiotic use. However, after multivariate logistic regression analysis according to sex, birth weight, gestational age and maternal age, only increased risk of respiratory morbidity was found to be continuous (RR: 1.28 [1.021.59 ]; $p=0.02$ ). Due to the evaluation of early term and full time term neonates hospitalized in the NICU, the need for admission to the NICU was evaluated by the significance test of the difference between the two percentages, but multivariate logistic regression analysis was not performed. However, the need for admission to the NICU was higher in the early term group.

\section{Discussion}

Morbidity caused by physiological immaturity in the neonatal period has been frequently examined in premature babies (3). Current studies showed that neonatal morbidities decrease in later gestational weeks and that babies born at 37 and $38 \mathrm{GW}$ have higher morbidity compared to babies born at 39 weeks (5). In the present study $30 \%$ of live births were early term births. In the USA, $27,6 \%$ of the deliveries were reported to be caused by early term pregnancies (10). In a multicenter study the rate of early term births was reported to be $25 \%$, which was similar to our results. The same study results indicated the number of early term newborns as 3 times the number of late premature newborns (11). Similarly, this ratio was found to be 2,6 in our study.

When adolescent pregnancy rates were compared, no statistically significant difference was found between the groups. In one study adolescent pregnancies were reported to be higher in the full-term group (11). Contrary to that, Parikh et al. reported adolescent pregnancy rate was higher in early term group (12). 
While the birth rate with $\mathrm{C} / \mathrm{S}$ was $62 \%$ in the early term group, this rate was $50 \%$ in the full-term group and was statistically significant. Although $\mathrm{C} / \mathrm{S}$ rates did not show similarity, cesarean delivery rate was higher in the early term group, similar to the literature. It is well-known that delivery with $\mathrm{C} / \mathrm{S}$ without labor is an important factor causing morbidity in newborns (13). Delivery with $\mathrm{C} / \mathrm{S}$ was reported to cause longer hospital stay and more respiratory morbidities $(11,12)$. In our study, the most common cause of hospitalization was respiratory morbidities.

Concomitant maternal diseases before or during pregnancy are one of the major causes of morbidity and even mortality in newborns (14). Concomitant maternal diseases were significantly higher in the early term group. The most common maternal disease was diabetes, followed by hypothyroidism, preeclampsia and eclampsia followed by maternal diabetes. It is known that hypoglycemia, electrolyte disturbances, indirect hyperbilirubinemia respiratory morbidities such as TTN and RDS are more common in infants of diabetic mothers (15). Early termination of pregnancy due to these diseases may lead to an increase in neonatal morbidities and the effects of maternal diseases on the baby may be the cause of these morbidities.

LBW and SGA infant rates were found to be significantly higher in the early term group as expected. In contrast, the number of LGA infants was also higher in the full-term group. Two large studies evaluating early term and full-term morbidity rates reported high rates of LBW infants in the early term group, similar to our study $(11,12)$.

Multiple pregnancies account $3-4 \%$ of all pregnancies. It is known that multiple pregnancies can cause congenital anomalies, fetal growth retardation, and increase in RDS and TTN together with neonatal mortality (16). In our study, multiple pregnancies accounted 2,5\% of term newborns and were significantly higher in the early term group. We think that multiple pregnancies may be one of the factors effecting higher morbidity rates in the early term group.

The early term group was found to be hospitalized more in the NICU. It is frequently emphasized in the literature that early term newborns need to be admitted to the NICU or neonatal ward more frequently which was similar to our findings $(17,18)$.
In the present study, respiratory morbidities were significantly higher in the early term group. This finding was more pronounced for TTN, which is one of the most common cause of respiratory distress in newborns. Higher SGA rates, delivery with $\mathrm{C} / \mathrm{S}$, accompanying maternal diseases such as diabetes and physiologically immaturity of the early term newborns could be the possible reason for this finding $(11,19)$.

Although respiratory morbidities were found to be higher in the early term group and there was a higher need for respiratory support (including mechanical ventilation or intubation and surfactant therapy), the groups did not significantly differ. Contrary to this finding, early term group was reported to be at higher risk for both parameters in one study (11).

Hypoglycemia and other electrolyte disorders are common morbidities in the newborn period and often have underlying risk factors $(15,20)$. When the groups were compared, metabolic disorders were significantly higher in the early term group. The most common metabolic disorders were hypoglycemia and hypernatremia, respectively. Hypoglycemia was found to be higher in early term group and hypernatremia was higher in full-term group.

Hypoglycemia is reported to be a more common morbidity in early term newborns. In our study, the reason for more frequent hypoglycemia is more babies born to diabetic mothers, and higher rates of SGA and LBW newborns in the early term group.

Increased water loss, insufficient water intake and excessive sodium intake are three main causes of hypernatremia in the newborn period (21). Although hypernatremic dehydration is frequently seen in term newborns, premature and SGA infants are at risk (22). A Canadian study reported that the shortening of the length of hospital stay caused higher rates of re-hospitalization, dehydration, jaundice, nutritional problems and inadequate weight gain (23). Although not included in our study, early discharge of fullterm newborns, may be a reason for more frequent occurrence of hypernatremia in full-term group.

The need for iv antibiotic therapy was higher in the early term group in our study, as indicated in the literature (11). Higher admission rates to NICU, empiric antibiotic treatment because of maternal risk factors (early rupture of membranes, chorioamnionitis, urinary tract infection, positive cervical culture), elevation of acute phase reactants, 
worsening of medical situation, and findings suggestive of clinical sepsis could be the possible reasons for this finding.

Although the groups did not differ in terms of need for intubation, mechanical ventilation and the use of surfactant; the total number of patients were higher in the early term group. The initiation of antibiotic treatment empirically to these patients could have led to more use of antibiotics in the early term group.

Maternal comorbidities, ceserean delivery, low birth weight, SGA and multiple gestations were found to be higher in early-term infants and also early-term infants were at higher risk for respiratory morbidities, respiratory support requirement, hypoglycemia and need for intravenous antibiotic therapy. After multivariate logistic regression analyses, only higher risk for respiratory morbidity persisted (OR:1.28 [1.02$1.59] ; \mathrm{p}=0.02$ ). In contrast to that, full-term infants was found to be at higher risk for hypernatremia compared to early-term infants.

\section{Conclusion}

Early term birth is associated with a higher neonatal morbidity and NICU admissions, and gestational age is known to be the most important determinant of this situation. Therefore, with advanced maternal care and better understanding of the factors causing early term birth will lead to prevention and successfull management of this risk group. For this purpose more, and larger, multicenter studies are needed.

\section{Ethics}

Ethics Committee Approval: Parental informed consent was obtained from all individual participants included in the study. Ethics committee approval was received from Zekai Tahir Burak Womens' Health Training and Research Hospital Training Planning Board. Ethics committee certificate date and no: 02.06.2014-0020.

Conflict of Interest: No conflict of interest was declared by the authors.

Financial Disclosure: The authors declared that this study received no financial support.

\section{References}

1. Clark SL, Fleischman AR. Term pregnancy: time for a redefinition. Clin Perinatol 2011;38: 557-64.
2. Engle WA. Morbidity and mortality in late preterm and early term newborns: a continuum. Clin Perinatol 2011;38:493516.

3. Catalano PM, Sacks DA. Timing of indicated late preterm and early-term birth in chronic medical complications: diabetes. Semin Perinatol 2011;35:297-301.

4. Gouyon JB, Vintejoux A, Sagot P, Burguet A, Quantin C, Ferdynus $\mathrm{C}$, et al. Neonatal outcome associated with singleton birth at 34-41 weeks of gestation. Int J Epidemiol 2010;39:76976.

5. Reddy UM, Bettegowda VR, Dias T, Yamada-Kushnir T, Ko CW, Willinger M. Term Pregnancy: A Period of Heterogeneous Risk for Infant Mortality. Obstet Gynecol 2011;117:1279-87.

6. Hourani M, Ziede F, Rajab M. Timing of planned caesarean section and the morbidities of the newborn. N Am J Med Sci 2011;3:465-8.

7. De Luca R, Boulvain M, Irion O, Berner M, Pfister RE. Incidence of early neonatal mortality and morbidity after late-preterm and term cesarean delivery. Pediatrics 2009;123: 1064-71.

8. Boyle EM, Poulsen G, Field DJ, Kurinczuk JJ, Wolke D, Alfirevic Z, et al. Effects of gestational age at birth on health outcomes at 3 and 5 years of age: population based cohort study. BMJ 2012;344:e869.

9. Fleischman AR, Oinuma M, Clark SL. Rethinking the definition of "term pregnancy." Obstet Gynecol 2010;116:136-9.

10. Martin JA, Hamilton BE, Ventura SJ, Osterman MJK, Kirmeyer S, Mathews TJ, et al. Births: final data for 2009. Natl Vital Stat Rep 2011;60:1-70.

11. Sengupta S, Carrion V, Shelton J, Wynn RJ, Ryan RM, Singhal $\mathrm{K}$, et al. Adverse neonatal outcomes associated with early-term birth. JAMA Pediatr 2013;167:1053-9.

12. Parikh LI, Reddy UM, Männistö T, Mendola P, Sjaarda L, Hinkle $\mathrm{S}$, et al. Neonatal outcomes in early term birth. Am J Obstet Gynecol 2014;211:265.

13. Tita AT, Landon MB, Spong CY, Lai Y, Leveno KJ, Varner MW, et al. Timing of elective repeat cesarean delivery at term and neonatal outcomes. N Engl J Med 2009;360:111-20.

14. Esakoff TF, Cheng YW, Sparks TN, Caughey AB. The association between birthweight 4000 gr or greater and perinatal outcomes in patients with and without gestational diabetes mellitus. Am J Obstet Gynecol 2009;200:672.

15. Infant of A Diabetic Mother. In: Gomella TL, Cunningham MD, Eyal FG (eds). Lange Neonatology. 7th ed. Mc Grow-Hill Education; 2013.p. 709-15

16. Carlo WA. Multiple Gestation Pregnancies. In: Kliegman RM, Stanton BF, St. Geme JW, (eds). Nelson Textbook of Pediatrics. 19th ed. Elsevier saunders; 2011. p. 553-5.

17. Zhang X, Kramer MS. Variations in mortality and morbidity by gestational age among infants born at term. J Pediatr 2009; 154:358-62.

18. Reddy UM, Ko CW, Willinger M. "Early" term births (37-38 weeks) are associated with increased mortality. Am J Obstet Gynecol 2006;195:202.

19. Levine EM, Ghai V, Barton JJ, Strom CM. Mode of delivery and risk of respiratory diseases in newborns. Obstet Gynecol 2001;97:439-42.

20. Liu J, Wang XF, Wang Y, Wang HW, Liu Y. The incidence rate, high-risk factors, and short- and long-term adverse outcomes of fetal growth restriction: a report from Mainland China. Medicine (Baltimore) 2014;93:e210. 
21. Dell Macrae K. Fluid, electrolytes, and acid-base homeostasis. In: Martin RJ, Fanaroff AA, Walsh MC (eds). Fanaroff and Martin's neonatal-perinatal medicine. 10th ed. Elsevier Saunders; 2015. P. 613-29.

22. Laing IA, Wong CM. Hypernatraemia in the first few days: is the incidence rising? Arch Dis Child Fetal Neonatal Ed 2002;87:15862.
23. McIntire DD, Leveno KJ. Neonatal mortality and morbidity rates in late preterm births compared with births at term. Obstet Gynecol 2008;111:35-41.

24. Fenton TR. A new growth chart for preterm babies: Babson and Benda's chart updated with recent data and a new format. BMC Pediatr 2003;3:13. 